\title{
Synthesis of enantiomerically pure (d) - doxylamine using a novel chiral auxiliary
}

\author{
Christabel Nang'andu HIKAAMBO ${ }^{1,3 *}$, Hanzooma HATWIKO ${ }^{1,2}$, \\ Derick MUNKOMBWE ${ }^{1}$, Aubrey Chichonyi KALUNGIA ${ }^{1}$ Chiluba MWILA $^{\mathrm{I}}$, \\ Steward MUDENDA ${ }^{1}$, Ronald Kampamba MUTATI ${ }^{1}$, Martin KAMPAMBA ${ }^{1}$ and \\ Hee Doo KIM ${ }^{3}$
}

\author{
${ }^{I}$ Department of Pharmacy, University of Zambia, P.O Box 32379, Lusaka, Zambia. \\ ${ }^{2}$ Department of Chemistry, University of Zambia, P.O Box 50110, Lusaka, Zambia. \\ ${ }^{3}$ College of Pharmacy, Sookmyung Women's University, Yongsan-gu 140-742, Seoul, South Korea. \\ "Corresponding author; E-mail: christabel.hikaambo@unza.zm, xbellhikaambo@gmail.com, \\ P.O. Box 50110, Lusaka, Zambia.
}

Received: 28-01-2021 $\quad$ Accepted: 27-09-2021 $\quad$ Published: 30-10-2021

\begin{abstract}
It is known that the main mode of synthesis of doxylamine is a racemic mixture. However, the active enantiomers of the compound show superior activity to that of the racemate, thus the need to synthesize doxylamine as an enantiopure compound. This study aimed to synthesise an enantiopure (d)-doxylamine and it was achieved through the use of optically active diols synthesised from a novel chiral auxiliary. While most available methods employ Sharpless asymmetric dihydroxylation, this study reports a method that achieves superior enantiomeric excess with consequent better yields of $67 \%$ of end products not easily accessible by use of Sharpless Asymmetric Dihydroxylation.

(C) 2021 International Formulae Group. All rights reserved.
\end{abstract}

Keywords: Antihistamine, chiral doxyalamine, (R)-1-phenyl-1-(pyridin-2-yl) ethanol, chiral 1, 2-diols, enantiomeric excess, Sharpless asymmetric dihydroxylation.

\section{INTRODUCTION}

Doxylamine, chemically known as $\mathrm{N}$, N-Dimethyl-1-2-[1-phenyl-1-(2-pyridinyl) ethoxy] ethanamine, is a highly sedative aminoalkylether and is used clinically in the short-term treatment of insomnia, symptomatic relief of allergic reactions, treatment of pruritic skin disorders and management of nausea and vomiting in pregnancy (Tadiboyina et al., 2015). This medicine is chiral and has a single chiral centre. Doxylamine, however, is most widely available and used as a racemic mixture in clinical settings. It has been reported in the patent filing documents that (d)-doxylamine is more efficient in arresting allergic reactions and improving sleep compared to its racemic form (Patti, 2011).

Currently, the main mode of synthesis of doxylamine is a racemic mixture. However, active enantiomers of a compound show a superior activity to that of the racemate. Additionally, any two possible enantiomers of 
a chiral compound such as doxylamine usually possess variable biological activities. Therefore, the need to synthesize doxylamine as an enantiopure compound cannot be overemphasized (McConathy and Owens, 2003).

Most drugs are chiral, and their pharmacological activity depends mainly on their interaction with biological targets like proteins, nucleic acids, and biomembranes. Importantly, one enantiomer of a chiral drug may be a medicine useful for treating diseases while another may either be inactive or toxic (Reshma et al., 2018). Drug chirality influences both the interaction of these compounds with biological targets as well as the pharmacokinetics of drugs (Reshma et al., 2018).

Synthesis of doxylamine can be achieved by reacting a Grignard reagent generated by iodobenzene and magnesium with 2-acetylpyridine to generate 2-pyridyl phenyl methyl alcohol. 2-pyridyl phenyl methyl alcohol then reacts with sodium amide and 2dimethylamino chloroethane sequentially (Jinyuan et al., 2013). Racemate doxylamine can also be synthesised using 2-acetylpyridine and bromobenzene with magnesium turnings to generate in-situ Grignard reagent in the presence of anhydrous ether followed by reaction with 2-dimethylaminoethyl chloride using a strong base sodamine in xylene (Nilesh, 2016). However, chiral doxylamine succinate can be prepared by reacting 2-acetopyridine and phenylboronic acid in toluene solvent using chiral ligand, diethylzin and $\mathrm{Ti}(\mathrm{iPO})_{4}$ followed by reacting with 2-dimethyl aminoethyl chloride (Fukangren Biopharm-Sci $\mathrm{R}, 2013)$. This process is complicated to operate and requires costly chiral reagents and a longer reaction time with tedious workup (Nilesh, 2016). Thus, this study supports the synthesis of drugs as also reported in other studies (Bamba et al., 2021; Samuel and Adekunle, 2021; Kouamé et al., 2021; Chawe et al., 2021).

There is a need to develop new methods of asymmetric synthesis of Doxylamine. Therefore, this study was aimed at synthesising enantiopure (d)-doxylamine from optically active diols using a novel chiral auxiliary.

\section{MATERIALS AND METHODS Experimental General}

${ }^{1} \mathrm{H}$ NMR and ${ }^{13} \mathrm{C}$ NMR spectra were recorded on a Varian Inova 400 Spectrometer and chemical shifts were shown as values in parts per million relative to tetramethylsilane as an internal standard (. The melting points of all compounds were determined using a MELTEMP ${ }^{\circledR}$ apparatus while infrared (IR) spectra were recorded on a NICOLET IS5 FT/IR spectrometer. Column chromatography was conducted using the forced flow solvent on Merck Kieselgel 60(230-400mesh). Thin-layer chromatography was carried out on $0.25 \mathrm{~mm}$ E. Merck precoated silica gel glass plates. All solvents were distilled with calcium hydride except tetrahydrofuran (THF) which was distilled from sodium benzophenone under a nitrogen atmosphere. Unless otherwise indicated, all chemicals were purchased from commercially available sources and used without additional purification.

Synthesis of $(R)-((R)-2,2-d i m e t h y l-1,3-$ dioxolan-4yl) (4-methoxyphenyl) methanol(4)

Copper iodide ( $2.05 \mathrm{~g}, 10.76 \mathrm{mmol})$ was added to a flask with THF: DMS (5:1) then cooled to $\left(-78^{\circ} \mathrm{C}\right)$. Then 4-methoxyphenyl magnesium bromide ( $0.5 \mathrm{M}$ solution in THF, 18 $\mathrm{ml}, 9.22 \mathrm{mmol}$ ) was added to the mixture and stirred for 20 minutes followed by the addition of 2,3-O-isopropylidene-D-glyceraldehyde (1 $\mathrm{g}, 7.68 \mathrm{mmol}$ ) through a cannula in THF. The resulting mixture was stirred continually at $-78^{\circ} \mathrm{C}$ while gradually increasing the temperature for an additional 2 hrs. The resulting product was checked by TLC to confirm its purity. The reaction was then quenched with $\mathrm{NH}_{4} \mathrm{Cl}: \mathrm{NH}_{4} \mathrm{OH}$ (9:1) then stirred for 30 minutes. After which workup was done using $\mathrm{NH}_{4} \mathrm{Cl}$ : $\mathrm{NH}_{4} \mathrm{OH}$ (9:1), EtOAc, water, brine and dried over anhydrous $\mathrm{Na}_{2} \mathrm{SO}_{4}$. The resulting mixture was concentrated and purified using column chromatography ( $\mathrm{n}$ Hexane: EtOAc=5:1) to give title compound 4 as a solid (502 $\mathrm{mg}, 27 \%)$. 


\section{Synthesis of 2-((R)-((R)-2,2-dimethyl-1,3- dioxolan-4-yl) (4-methoxyphenyl) methoxy)- 1-phenylethanol (5)}

To a suspension of KH ( $84 \mathrm{mg}, 30 \%$ in oil, $0.63 \mathrm{mmol})$ in THF (3 ml) was added a solution of alcohol $1(100 \mathrm{mg}, 0.42 \mathrm{mmol})$ in THF. The mixture was stirred at $55^{\circ} \mathrm{C}$ for 30 minutes then cooled to RT. At RT, styrene oxide $(75.7 \mu \mathrm{L}, 0.63 \mathrm{mmol})$ and 18 -crown- $6(5$ $\mathrm{mg}$ ) was added then refluxed at $55^{\circ} \mathrm{C}$ for $24 \mathrm{hrs}$. The reaction mixture was quenched with aq. $\mathrm{NH}_{4} \mathrm{Cl}(5 \mathrm{~mL})$ and diluted with ethyl acetate $(50 \mathrm{~mL})$. The organic layer was washed with brine and water then dried over anhydrous $\mathrm{Na}_{2} \mathrm{SO}_{4}$, filtered and concentrated. The resulting crude residue was purified by column chromatography on silica gel using (n-Hexane: $\mathrm{EtOAc}=5: 1)$ to give compound $\mathbf{5}$ as an oil (58 $\mathrm{mg}, 39 \%)$.

$$
R_{\mathrm{f}}=0.25 \text { (n-Hexane: EtOAc }=2: 1 /
$$
anisaldehyde)

${ }^{1} \mathrm{H} \quad \mathrm{NMR} \quad\left(400 \mathrm{MHz}, \quad \mathrm{CDCl}_{3}\right): \quad \delta$ $7.25(\mathrm{~m}, 7 \mathrm{H}), \quad 6.86(\mathrm{~m}, 2 \mathrm{H}), \quad 4.86(\mathrm{~m}, \quad 1 \mathrm{H})$, 4.34(m,1H), $4.27(\mathrm{~m}, 1 \mathrm{H}), \quad 3.79(\mathrm{~s}, 3 \mathrm{H})$, $3.61(\mathrm{~m}, 2 \mathrm{H}), 3.51(\mathrm{~m}, 1 \mathrm{H}), 3.37(\mathrm{t}, J=10 \mathrm{~Hz}, 1 \mathrm{H})$, $3.29(\mathrm{t}, J=10 \mathrm{~Hz}, 1 \mathrm{H}), 1.47(\mathrm{~s}, 3 \mathrm{H}), 1.39(\mathrm{~s}, 3 \mathrm{H})$

${ }^{13} \mathrm{C} \mathrm{NMR}\left(100 \mathrm{MHz}, \mathrm{CDCl}_{3}\right): \delta 159.82$, $139.93,129.84,128.71,128.54,128.26$, $127.67,127.63,126.12,114.13,114.07$, $110.24,85.56,79.3,77.34,66.08,55.25,26.72$, 25.53

IR (Neat, $\left.\mathrm{cm}^{-1}\right)$ : 2987, 1610, 1512, 1454, 1264 Synthesis of 2-((R)-((R)-2,2-dimethyl-1,3dioxolan-4-yl) (4-methoxyphenyl) methoxy)1-phenylethanone (6)

2-((R)-((R))-2,2-dimethyl-1,3-

dioxolan-4-yl(4-methoxyphenyl)methoxy)-1phenyl ethanol (100 mg, $0.279 \mathrm{mmol})$ was added to the flask and mixed with 4methylmorphine N-Oxide $(65 \mathrm{mg}, 0.558$ mmol) in methylene chloride $10 \mathrm{ml}$. The mixture was stirred for 10 minutes, and then tetra propylammonium perrutherate $(10 \mathrm{mg}$, $0.028 \mathrm{mmol}$ ) was added and stirred for another 1 hour at room temperature. The reaction mixture was quenched with saturated aqueous sodium sulfite $(1 \mathrm{ml})$ then diluted with ethyl acetate. The organic layer was washed with brine, copper sulfate solution, and water and dried over anhydrous $\mathrm{Na}_{2} \mathrm{SO}_{4}$, filtered then concentrated. The crude residue was purified by column chromatography (n-Hexane: EtOAc=5:1) to give the compound as a white solid (82 mg, 86\%).

Synthesis of $(R)-2-((R)-((R)-2,2-d i m e t h y l-1,3-$ dioxolane-4yl) (4-methoxyphenyl) methoxy)1-phenyl-1-(pyridine-2-yl) ethanol (7)

2-bromopyridine $(80 \mu \mathrm{L}, 0.842 \mathrm{mmol})$ was added to a flask with $5 \mathrm{ml}$ toluene and cooled to $-78{ }^{\circ} \mathrm{C}$. To the reaction mixture was added dropwise n-Butyl lithium (336.8 $\mu \mathrm{L}$, $0.842 \mathrm{mmol}, 2.5 \mathrm{M}$ solution in Hexane) via a syringe then stirred for 30 minutes. 2-((R)((R)-2, 2-dimethyl-1, 3-dioxolan-4yl) (4methoxyphenyl) methoxy)-1phenylethanone $(100 \mathrm{mg}, 0.28 \mathrm{mmol})$ was added and stirred for another $2 \mathrm{hrs}$ at $-78{ }^{\circ} \mathrm{C}$. The reaction mixture was quenched with water and diluted with ethyl acetate. The organic layer was washed with water, brine, dried over anhydrous $\mathrm{Na}_{2} \mathrm{SO}_{4}$, filtered and concentrated. The crude product was purified by column chromatography (n-Hexane: EtOAc $=3: 1$ ) to give the compound as a pale-yellow oil (58.4 mg, 67\%)

Synthesis of 1-phenyl-1-(pyridine-2-yl) ethane-1, 2-diol (8)

a) (R)-2-((R)-((R)-2,2-dimethyl-1,3dioxolane-4-yl)(4methoxyphenyl) methoxy)-1-phenyl-1-(pyridine-2yl)ethanol ( $26 \mathrm{mg}, 0.06 \mathrm{mmol})$ was mixed with acetonitrile $(3 \mathrm{ml})$, Tin(II) chloride (1.1 mg,0.006 mmol, 0.1 eq), chlorotrimethylsilane $(23 \mu \mathrm{L}, 0.18 \mathrm{mmol}, 3$ eq) and sodium Iodide ( $27 \mathrm{mg}, 0.18 \mathrm{mmol}$, 3 eq) and stirred at $-20^{\circ} \mathrm{C}$ for $1 \mathrm{hr}$. The reaction mixture was then quenched with $\mathrm{NaHCO}_{3}$ and diluted with ethyl acetate (50 $\mathrm{ml})$. The organic layer was washed with water, brine then dried over anhydrous $\mathrm{Na}_{2} \mathrm{SO}_{4}$, filtered and concentrated. The crude product was then purified by column chromatography using (n-Hexane: EtOAc $=2: 1)$ to give a white solid product $(3 \mathrm{mg}$, $19 \%)$.

b) $\mathrm{K}_{3} \mathrm{Fe}(\mathrm{CN})_{6}(599 \mathrm{mg}, 1.82 \mathrm{mmol}), \mathrm{K}_{2} \mathrm{CO}_{3}$ (251 mg, $1.82 \mathrm{mmol}$ ), $\mathrm{K}_{2} \mathrm{OsO}_{4} .2 \mathrm{H}_{2} \mathrm{O}$ (cat) (DHQD) 2 PHAL (10.4 mg, $0.013 \mathrm{mmol}$ ) 
and $(\mathrm{R})-2-((\mathrm{R} \quad)-((\mathrm{R})-2,2-$ dimethyl-1,3dioxolane-4-yl)(4methoxyphenyl)methoxy)-1-phenyl-1(pyridine-2-yl)ethanol (110 mg, 0.607 mmol) were added to a flask containing 10 $\mathrm{ml}$ tert-Butanol: $\mathrm{H}_{2} \mathrm{O}(1: 1)$ at $0^{\circ} \mathrm{C}$. The reaction mixture was stirred at $0^{\circ} \mathrm{C}$ overnight, then added sodium sulfite (6 eq) and stirred for another 30 minutes. The mixture was then diluted with methylene chloride and washed with $\mathrm{NaHCO}_{3}, \mathrm{H}_{2} \mathrm{O}$, brine followed by drying over anhydrous $\mathrm{Na}_{2} \mathrm{SO}_{4}$. The resulting crude product was purified by the use of column chromatography (n-Hexane: EtOAc $=1: 1)$ to give a white solid (49 mg, 38\%).

Synthesis of a (R)-2-hydroxy-2-phenyl-2(pyridine-2yl) ethyl methane sulfonate (9)

To a solution of diol $(65 \mathrm{mg}, 0.30$ mmol) in $4 \mathrm{ml}$ pyridine was added methane sulfonyl chloride $(116 \mu \mathrm{L}, 1.50 \mathrm{mmol})$ and stirred at $0^{\circ} \mathrm{C}$ for $3 \mathrm{hrs}$. The reaction mixture was then quenched with water, diluted with methylene chloride, and then the organic layer was washed with brine and dried over anhydrous $\mathrm{Na}_{2} \mathrm{SO}_{4}$. The crude product was purified by column chromatography (nHexane: $\mathrm{EtOAc}=2: 1)$ to give the product in $(73$ $\mathrm{mg}, 83 \%$ ) yield.

$R_{\mathrm{f}}=0.4\left(\mathrm{n}-\mathrm{Hexane}: \mathrm{EtOAc}=1: 1 / \mathrm{KMnO}_{4}\right)$

Melting point $=66-68^{\circ} \mathrm{C}$

${ }^{1} \mathrm{H}$ NMR $\left(400 \mathrm{MHz}, \mathrm{CDCl}_{3}\right): \delta 8.54(\mathrm{~d}$, $J=4,1 \mathrm{H}), 7.70(\mathrm{~m}, 1 \mathrm{H}) 7.47(\mathrm{~m}, 3 \mathrm{H}), 7.30(\mathrm{~m}$, $4 \mathrm{H}), 5.55(\mathrm{~s}, 1 \mathrm{H}), 4.92(\mathrm{~d}, J=10.8,1 \mathrm{H}), 4.75(\mathrm{~d}$, $J=10.8,1 \mathrm{H})$

${ }^{13} \mathrm{C}$ NMR $\left(100 \mathrm{MHz}, \mathrm{CDCl}_{3}: \delta 159.55\right.$, $147.85,141.4,137.3,128.55,128.03,126.02$, 123.0, 121.18, 77.33, 77.01, 76.82, 76.69, $74.51,37.64$

IR (Neat, $\mathrm{cm}^{-1}$ ): 3466, 3039, 3019, 2942, 1588, 1571, 1342, 1178

\section{Synthesis of (R)-2-(2-phenyloxiran-2-yl) pyridine (10)}

To a solution of mesylate $(40 \mathrm{mg}, 0.136$ mmol) in $3 \mathrm{ml}$ of DMF was added sodium hydride $(21.8 \mathrm{mg}, 0.546 \mathrm{mmol}, 4 \mathrm{eq}$, in $6 \%$ oil). The reaction mixture was then stirred at $0^{\circ} \mathrm{C}$ for $2 \mathrm{hrs} 30 \mathrm{~min}$ followed by quenching of the reaction mixture with water $(2 \mathrm{ml})$ and diluting with EtOAc. The organic layer was washed with water and brine several times then dried over anhydrous $\mathrm{Na}_{2} \mathrm{SO}_{4}$. The crude residue was purified by column chromatography (nHexane: EtOAc= 10:1) to give a syrup product (12 mg, 47\%) $\left.\mathrm{KMnO}_{4}\right)$

$R_{\mathrm{f}}=0.43(\mathrm{n}-\mathrm{Hexane}: \quad$ EtOAc $=3: 1 /$

${ }^{1} \mathrm{H}$ NMR $\left(400 \mathrm{MHz}, \mathrm{CDCl}_{3}\right): \delta 8.59(\mathrm{t}$, $1 \mathrm{H}), 7.65(\mathrm{~m}, 1 \mathrm{H}), 7.36(\mathrm{~m}, 5 \mathrm{H}), 7.20(\mathrm{~m}, 2 \mathrm{H})$, 3.53(dd, 1H), 3.24(dd, 1H)

${ }^{13} \mathrm{C}$ NMR $\left(100 \mathrm{MHz}, \mathrm{CDCl}_{3}\right): \delta 158.48$, $149.20,138.25,136.62,128.29,128.06$, $127.35,122.84,122.47,77.31,77.0,76.68$, 56.10

IR (Neat, $\left.\mathrm{cm}^{-1}\right): 3055,1586,1568$, 1446, 1175

\section{Synthesis of (R)- 1-phenyl-1-(pyridine-2-yl) ethanol (11)}

To a solution of epoxide $\mathbf{1 0}(8 \mathrm{mg}$, $0.041 \mathrm{mmol}$ ) in $10 \mathrm{ml}$ of THF was added lithium aluminium hydride $(6.16 \mathrm{mg}, 0.162$ mmol, 4 eq) and stirred at RT overnight. The reaction mixture was then quenched with few drops of water and allowed to stir for an hour. The mixture was then glass filtered with EtOAc, dried over $\mathrm{Na}_{2} \mathrm{SO}_{4}$ then purified using (n-Hexane: EtOAc $=10: 1)$ to give $(2.3 \mathrm{mg}$, $28 \%$ ) syrup product.

\section{RESULTS}

Synthesis of Chiral auxiliary

Chiral auxiliary 4 (scheme 3) was

prepared from (R) - glyceraldehyde diacetonide 3 giving the chemical yield of $27 \% . R_{\mathrm{f}}=0.60(\mathrm{n}-\mathrm{Hexane}:$ EtOAc $=1: 1 /$ anisaldehyde).

${ }^{1} \mathrm{H}$ NMR $\left(400 \mathrm{MHz}, \mathrm{CDCl}_{3}\right): \delta 7.29(\mathrm{~d}$, $J=4.8 \mathrm{~Hz}, 2 \mathrm{H}), 6.89(\mathrm{~d}, J=4.8 \mathrm{~Hz}, 2 \mathrm{H})$, $4.519(\mathrm{dd}, J=8.0,2.0 \mathrm{~Hz}, 1 \mathrm{H}), 4.22(\mathrm{q}, J=6.4 \mathrm{~Hz}$, $1 \mathrm{H}), 3.81(\mathrm{~s}, 3 \mathrm{H}), 3.78(\mathrm{dd}, J=8.4,6.0 \mathrm{~Hz}, 1 \mathrm{H})$, $3.68(\mathrm{dd}, \mathrm{J}=8.4,6.0 \mathrm{~Hz}, 1 \mathrm{H}), 2.73(\mathrm{~s}, 1 \mathrm{H})$, $1.50(\mathrm{~s}, 3 \mathrm{H}), 1.38(\mathrm{~s}, 1 \mathrm{H})$

${ }^{13} \mathrm{C} \mathrm{NMR}\left(100 \mathrm{MHz}, \mathrm{CDCl}_{3}\right): \delta 159.58,131.73$, 128.13(2c), 113.95(2c), 110.07, 80.25, 75.59, 66.00, 55.21, 26.93, 25.37

Melting point: $39-41^{\circ} \mathrm{C}$

IR $\left(\mathrm{KBr}\right.$ pellet, $\left.\mathrm{cm}^{-1}\right)$ : 3490, 3011, 2988, $1612,1514,1469,1253$ 


\section{Synthesis of Chiral auxiliary-conjugated $\alpha$ - alkoxy ketone}

Synthesis of compound 6 (scheme4) was achieved through the synthesis of compound 5 from chiral auxiliary $4 . \quad R_{\mathrm{f}}=$ 0.33(n-Hexane: EtOAc=3:1/anisaldehyde)

Melting point: $67-69^{\circ} \mathrm{C}$

${ }^{1} \mathrm{H}$ NMR $\left(400 \mathrm{MHz}, \mathrm{CDCl}_{3}\right): \delta 7.82(\mathrm{~m}, 2 \mathrm{H})$, $7.39(\mathrm{~m}, 3 \mathrm{H}), \quad 7.23(\mathrm{~m}, 2 \mathrm{H}), 6.85(\mathrm{~m}, 2 \mathrm{H})$, $4.64(\mathrm{~m}, 2 \mathrm{H}), 4.45(\mathrm{~m}, 2 \mathrm{H}), 3.76(\mathrm{~d}, J=2.8,3 \mathrm{H})$, $3.62(\mathrm{~m}, 1 \mathrm{H}), 3.55(\mathrm{~m}, 1 \mathrm{H}), 1.38(\mathrm{~d}, J=2.4,3 \mathrm{H})$, 1.34(d, $J=2.4$

${ }^{13} \mathrm{C}$ NMR $\left(100 \mathrm{MHz}, \mathrm{CDCl}_{3}\right): \delta 196.27,159.91$, $135.04,133.30,129.10,128.78,128.51$, $127.90,114.05,110.17,83.43,78.95,77.31$, $76.99,76.67,71.08,66.09,55.22,26.57,25.56$ IR (Neat, $\mathrm{cm}^{-1}$ ): 3018, 1358, 1214, 1174

\section{Asymmetric nucleophilic 1, 2-addition}

Compounds 7a and $\mathbf{7 b}$ (Scheme 5) were prepared from the reaction of compound 6 with 2-brompyridine in different solvents giving the following results.

$R_{\mathrm{f}}=7 \mathrm{a}: 0.41 \quad$ (n-Hexane: $\quad$ EtOAc $=1: 1 /$ anisaldehyde). 7b: 0.39 (n-Hexane: EtOAc $=$ 1:1/ anisaldehyde)

${ }^{1} \mathrm{H}$ NMR $\left(400 \mathrm{MHz}, \mathrm{CDCl}_{3}\right)$ :

7a: $\delta 8.47(\mathrm{~m}, 1 \mathrm{H}), 7.60(\mathrm{~m}, 4 \mathrm{H}), 7.15(\mathrm{~m}, 6 \mathrm{H})$, $6.80(\mathrm{~d}, J=8.4,2 \mathrm{H}), 4.93(\mathrm{~s}, 1 \mathrm{H}), 4.15(\mathrm{~m}, 4 \mathrm{H})$, $3.76(\mathrm{~m}, 3 \mathrm{H}), \quad 3.59(\mathrm{~m}, 1 \mathrm{H}), \quad 3.34(\mathrm{~m}, 1 \mathrm{H})$, $1.29(\mathrm{~s}, 6 \mathrm{H})$

7b: $\delta 8.48(\mathrm{~d}, J=4.8,1 \mathrm{H}), 7.61(\mathrm{t}, 2 \mathrm{H}), 7.50(\mathrm{t}$, $2 \mathrm{H}), 7.15(\mathrm{~m}, 6 \mathrm{H}), 6.81(\mathrm{t}, 2 \mathrm{H}), 5.09(\mathrm{~s}, 1 \mathrm{H})$, $4.44(\mathrm{~d}, \quad J=10,1 \mathrm{H}), \quad 4.22(\mathrm{~d}, \quad J=7.2, \quad 1 \mathrm{H})$, 4.14(m,1H), 3.77(s, 3H), 3.74(m, 1H), 3.59(m, $1 \mathrm{H}), 3.49(\mathrm{~m}, 1 \mathrm{H}), 1.31(\mathrm{~s}, 3 \mathrm{H}), 1.28(\mathrm{~s}, 3 \mathrm{H})$

${ }^{13} \mathrm{C}$ NMR $\left(100 \mathrm{MHz}, \mathrm{CDCl}_{3}\right)$ :

7a: $\delta$ 1.63.05, 159.56, 147.73, 143.97, 136.54, $129.79,128.71,127.95,126.98,126.13$, $122.02,121.36,113.78,109.80,83.94,78.99$, $77.92,77.32,77.01,76.69,75.10,65.81,55.20$, 26.51, 25.55

7b: $\delta 147.75,136.46,128.71(2 \mathrm{c}), 127.99$, 127.08(2c), $125.92, \quad 121.87, \quad 121.28$, $113.75(2 \mathrm{c}), \quad 109.85, \quad 84.33,79.04, \quad 77.98$, 77.30.76.98, 76.67, 75.44, 65.85, 55.21, 26.50, 25.56

IR (Neat, $\mathrm{cm}^{-1}$ ): 2985, 1610, 1586, 1511, 1454, 1371,1264

\section{Synthesis of optically active diol}

Optically active diols were synthesized from compound $\mathbf{7 a}$ by reacting it with trimethylsilyl chloride (TMSCl) and gave the following results.

$R_{\mathrm{f}}=0.25$ (n-Hexane: EtOAc $\left.=1: 1 / \mathrm{KMnO}_{4}\right)$

Melting point: $88-90^{\circ} \mathrm{C}$

${ }^{1} \mathrm{H}$ NMR $\left(400 \mathrm{MHz}, \mathrm{CDCl}_{3}\right): \delta 8.54(\mathrm{M}, 1 \mathrm{H})$, 7.69(m, 1H), 7.31(m, 7H), 5.25(s, 1H), 4.43(d, $1 \mathrm{H}, J=11.6 \mathrm{~Hz}), 3.97(\mathrm{~d}, 1 \mathrm{H}, J=11.2 \mathrm{~Hz}), 3.17(\mathrm{~s}$, 1H)

${ }^{13} \mathrm{C}$ NMR (100, $\left.\mathrm{CDCl}_{3}\right): \delta 147.44,137.29$, 128.31, 127.48, 125.91, 122.56, 122.10, 77.30, 76.99, 76.67, 69.34

IR (Neat, $\left.\quad \mathrm{cm}^{-1}\right): \quad 3269, \quad 3079, \quad 2943$, $1594,1569,1488,1478$

\section{Synthesis of methyl alcohol from optically active diol}

Methyl alcohol 11 was prepared from optically active diols by formation of an epoxide $\mathbf{1 0}$ then reducing with Lithium aluminium hydride (scheme 7).

$R_{\mathrm{f}}=0.34\left(\mathrm{n}-\mathrm{Hexane}:\right.$ EtOAc $\left.=5: 1 / \mathrm{KMnO}_{4}\right)$

${ }^{1} \mathrm{H}$ NMR $\left(400 \mathrm{MHz}, \mathrm{CDCl}_{3}\right): \delta 8.50(\mathrm{~m}, 1 \mathrm{H})$, 7.61(m, 1H), 7.49(m, 2H), 7.29(m, 3H), 7.14(m, 2H), 5.86(s, 1H), 1.92(s, 3H)

${ }^{13} \mathrm{C} \mathrm{NMR}\left(100 \mathrm{MHz}, \mathrm{CDCl}_{3}\right): \delta 164.73,147.39$, $136.98,128.20,126.97,125.87,122.03$, $120.28,77.38,77.07,76.74,75.06,29.22$ IR (Neat, $\mathrm{cm}^{-1}$ ): 3009, 1591, 1570, 1367.

\section{DISCUSSION}

Retrosynthetic analysis (scheme 1 and 2) of optically active doxylamine showed that it could be prepared from (R)-1-phenyl-1(pyridine-2-yl) ethane-1, 2-diol (chiral diol). Presently, many studies have shown preparation of optically active diols through Sharpless Asymmetric Dihydroxylation, however, the main problem with this mode of preparation is poor enantiomeric excess. In a study conducted by Wang et al., (2000), the enantiomeric excess (ee) of diols was found to be $20-35 \%$ ee after 10 days. The use of a novel chiral auxiliary provides a superior method of preparing optically active diols with good enantiomeric excess. Hence, in this study, a retrosynthesis of doxylamine through a novel chiral auxiliary assisted diol formation was used with a better enantiomeric excess (scheme 
1).

The synthesis of the target compound started with the preparation of chiral auxiliary conjugated $\alpha$-alkoxy ketone as a substrate for the diastereoselective nucleophilic 1, 2 addition reaction. Chiral auxiliary 4 was prepared from (R) - glyceraldehyde diacetonide 3 (Organic Synthesis, 1998) which was reacted with 4-methoxyphenyl magnesium bromide. 4-methoxyphenylmagnesium bromide is a bulky compound, so its addition to compound $\mathbf{3}$ is through the less hindered convex side according to Cram's chelation model (James Morrison, 2012) (Scheme 3). The chiral auxiliary 4 was then converted to its ether form by an o-alkylative epoxide ringopening reaction. This was achieved by first converting alcohol $\mathbf{4}$ to its corresponding alkoxide with $\mathrm{KH}$ in tetrahydrofuran (THF), followed by O-alkylation styrene oxide in the presence of 18-crown- 6 to make ether 5 in $36 \%$ yield. Thereafter, the resulting alcohol was oxidized by tetra propylammonium perruthnate (TPAP) in the presence of $\mathrm{N}$ - methylmorphine$\mathrm{N}$-oxide (NMO) to give a ketone 6 in $86 \%$ yield (Chang, 2008) (Scheme 4).

Ketone 6 was the main substrate and a short study was undertaken on it to determine the best conditions for asymmetric nucleophilic 1, 2- addition reaction. The condition included the use of different solvents THF, DCM and toluene. The optimum condition was observed with toluene at $-78^{\circ} \mathrm{C}$ to give the desired major product $\mathbf{7 a}$ and its diastereomer $\mathbf{7 b}$ in $67 \%$ chemical yield, in a $3: 1$ ratio and (50\% ee) of diastereomers (Table 1). The absolute configuration of the newly formed stereogenic centre of $7 \mathbf{a}$ could not be established at this stage but was assigned tentatively as (R) based on our proposed chelation model by Cram shown in Figure 1 .

Alcohol 7a was then converted to chiral 1,2 diol $\mathbf{8}$ by reacting with trimethylsilyl chloride (TMSCl) and sodium iodide (Chang, 2008). Chiral diols are generally readily prepared from an alkene by Sharpless asymmetric dihydroxylation. Compared to 20$35 \%$ enantiomeric excess of chiral diol found in Wang et al.(2000) study by use of Sharpless dihydroxylation, the use of chiral auxiliary assisted diol formation gave 50-67\% enantiomeric excess which was better(scheme 5). Doxylamine preparation requires the use of chiral 1, 2 diols with high enantiomeric excess, therefore, the asymmetric nucleophilic 1, 2addition (scheme 6) to an $\alpha$-alkoxy ketone can provide an alternative to chiral diols not easily accessible through Sharpless asymmetric dihydroxylation method. Selective mesylation of a diol with methanesulfonyl chloride in pyridine produced a mesylate $\mathbf{9}$ in $83 \%$ yield which was then treated with sodium hydride in DMF to afford epoxide $\mathbf{1 0}$ in $47 \%$ yields. Finally, treatment of epoxide $\mathbf{1 0}$ with lithium aluminium hydride in THF at RT caused ring opening of epoxide to afford tertiary alcohol 11(scheme 7) (Lee SY, 2015). The final chiral target compound can be prepared in a single reaction by reacting compound 11(tertiary alcohol) with N, N-dimethyl aminoethyl.
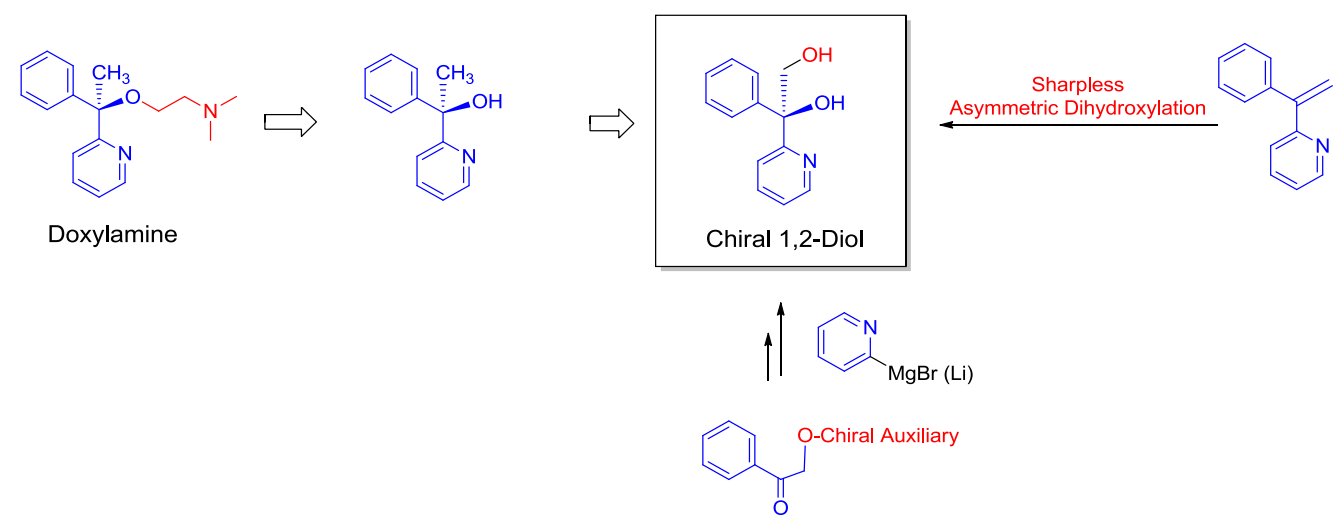

Scheme 1: Retrosynthetic analysis of chiral Doxylamine. 
<smiles>OC[C@@](O)(c1ccccc1)c1ccccn1</smiles><smiles>OC[C@@](O)(c1ccccc1)c1ccccn1</smiles><smiles>C1=CC=C1</smiles><smiles>[R6]CC(=O)c1ccccc1</smiles><smiles>COc1ccc([C@@H](C)[C@H]2COC(C)(C)O2)cc1</smiles>

Scheme 2: Retrosynthetic analysis of chiral auxiliary assisted diol formation.

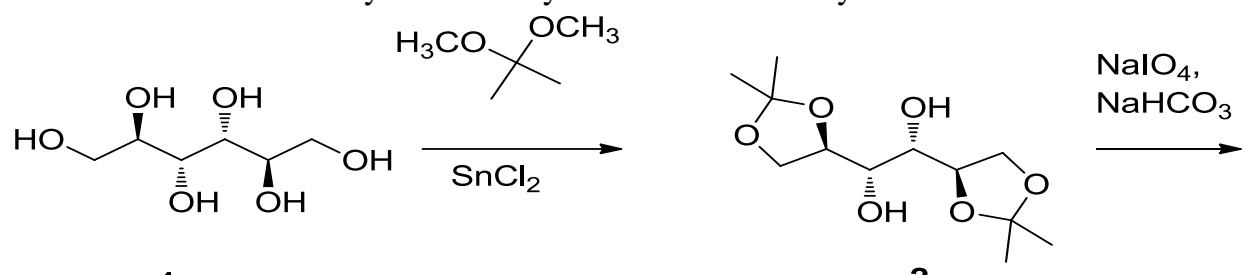

1<smiles>CC1(C)OCC(C=O)O1</smiles>

3<smiles>[CH2+]c1ccc(OC)cc1</smiles>

Scheme 3: Synthesis of Chiral auxiliary.<smiles>COc1ccc(C(O)C2COC(C)(C)O2)cc1</smiles>

4

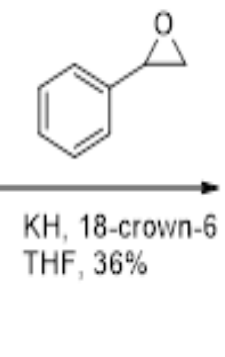

2<smiles>COc1ccc(C(O)C2COC(C)(C)O2)cc1</smiles>

4<smiles>COc1ccc([C@H](OCC(O)c2ccccc2)[C@H]2COC(C)(C)O2)cc1</smiles>

5

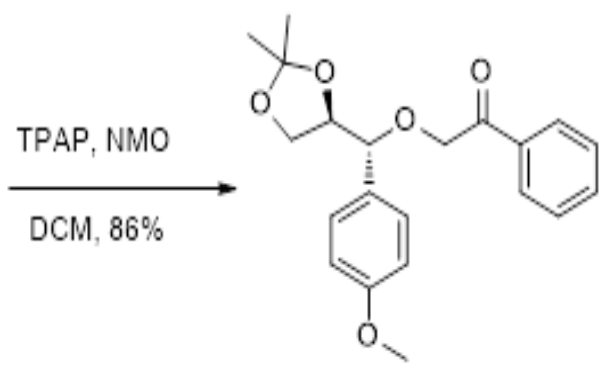

6

Scheme 4: Synthesis of Chiral auxiliary-conjugated $\alpha$-alkoxy ketone.

Table 1: Asymmetric nucleophilic 1, 2-addition.

\begin{tabular}{lllllll}
\hline Entry & Solvent & Temp $\left({ }^{\mathbf{O}} \mathbf{C}\right)$ & Additive & Yield (\%) & Ratio(7a:7b) & ee (\%) \\
\hline $\mathbf{1}$ & THF & -78 & None & 48 & $2: 1$ & 33 \\
\hline $\mathbf{2}$ & Toluene & -78 & None & 67 & $3: 1$ & 50 \\
\hline $\mathbf{3}$ & DCM & -78 & None & 35 & $2: 1$ & 33 \\
\hline $\mathbf{4}$ & DCM & -78 & $\mathrm{MgBr}_{2} \mathrm{OEt}_{2}$ & 11 & $5: 1$ & 67 \\
\hline
\end{tabular}

The ratio(R/S) was determined by NMR and percentage yield (\%) 
<smiles>COc1ccc([C@H](OCC(=O)c2ccccc2)[C@H]2COC(C)(C)O2)cc1</smiles>

6

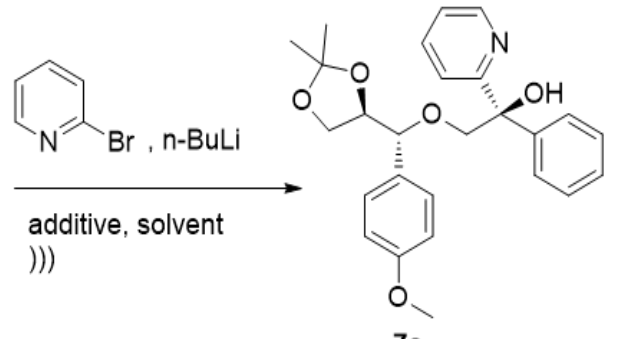

$7 \mathrm{a}$

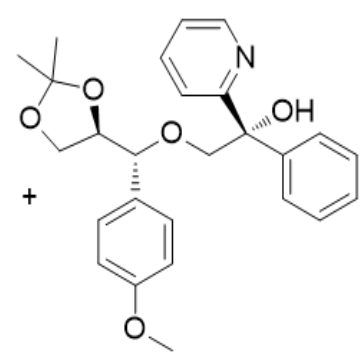

$7 \mathrm{~b}$

Scheme 5: Asymmetric nucleophilic 1, 2-addition.

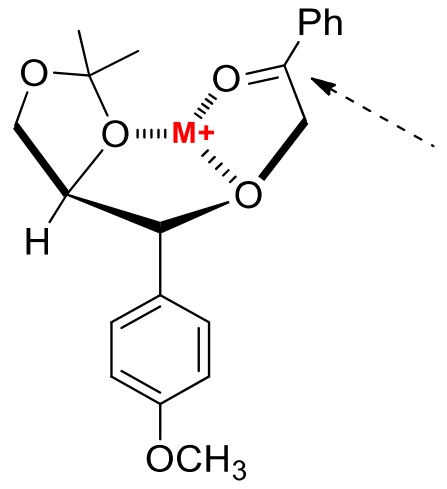

$\mathrm{Nu}^{-}$<smiles>C=C[Mg]Br</smiles>

Figure 1: Proposed possible chelation model for asymmetric nucleophilic 1, 2-addition.<smiles>COc1ccc([C@H](OC[C@@](O)(c2ccccc2)[C@H]2COC(C)(C)O2)c2ccccn2)cc1</smiles>

$7 a$<smiles>[SiH3][AsH2][AsH2][AsH3]</smiles><smiles>CCC(O)(CO)c1ccccc1</smiles>

8

Scheme 6: Synthesis of optically active diol.

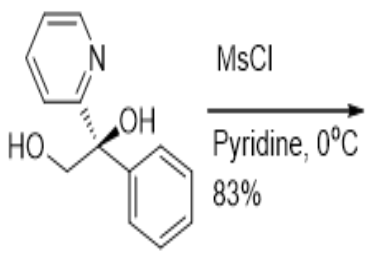

8

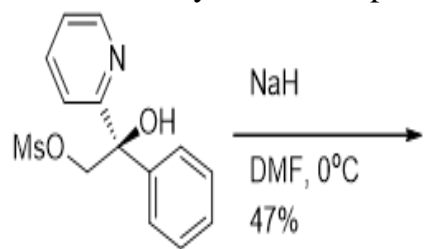

9<smiles>c1ccc([C@@]2(c3ccccn3)CO2)cc1</smiles>

10

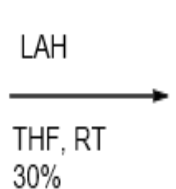<smiles>CC(O)(c1ccccc1)c1ccccn1</smiles>

11

Scheme 7: Synthesis of methyl alcohol from optically active diol. 


\section{Conclusion}

In summary, it has been established that (R)-1-phenyl-1-(pyridin-2-yl) ethanol 11 can be prepared better from chiral auxiliary through chelation-controlled diastereoselective nucleophilic 1,2-addition and reduction of primary protected alcohol. 1,4-asymmetric induction was also realized during the key alkylation step through a chelation-controlled mechanism. The synthetic method also provided an alternative way of preparing chiral 1,2-diols with the highest enantiomeric excess (ee) of $67 \%$ not easily accessible by use of Sharpless asymmetric dihydroxylation. We, therefore, advocate the use of a chiral auxiliary method as a better alternative way to synthesize Doxylamine.

\section{COMPETING INTERESTS}

The authors have not declared any competing interests.

\section{AUTHORS' CONTRIBUTIONS}

$\mathrm{CNH}$ and HDK conceptualized the study and planned the experiments. $\mathrm{CNH}$ and HH wrote the initial manuscript. DM, ACK, CM, SM, RKM, and MK helped in analysing the results. All authors reviewed the intellectual content of the manuscript. All authors approved the final version of the manuscript.

\section{ACKNOWLEDGEMENTS}

This research was made a success through the help and support of the team in a Medicinal Chemistry Laboratory at Sookmyung Women's University in South Korea.

\section{REFERENCES}

Akpa SJ, Zoakouma RS, Say VM, Ouattara M, Kone MW, Sissouma D, Adjou A. 2016. Synthesis and in vitro antifungal evaluation of 2-thioalkylarylbenzimidazoles derivatives against Candida albicans. Int. J. Biol. Chem. Sci., 10(3): $\quad$ 1403-1412. DOI: http://dx.doi.org/10.4314/ijbcs.v10i3.38

Bamba B, Benie CKD, Ouattara A, Doukourou DN, Kamou RK, Ouattara K. 2021. Teneurs en phénols totaux, activités antioxydantes des macérés et décocté des feuilles de Uvaria chamae P. Beauv. (Annonaceae). International Journal of Biological and Chemical Sciences, 15(1):54-67. DOI: 10.4314/ijbcs.v15i1.6.

Chang M, Kim TH, Kim HD.2008. Stereoselective synthesis of (+)Flutriafol.

Tetrahedron:Asymmetry19(12):15031507.

DOI: https://doi.org/10.1016/j.tetasy.2008.06.0 07

Chawe LCD, Tittikpina NK, Ndiaye SM, Diop A, Ndiaye B, Fall D, Diop YM, Sarr SO. 2021. Validation of an UV-Visible spectrophotometry assay method for the determination of chlorpheniramine maleate tablets without prior extraction. International Journal of Biological and Chemical Sciences, 15(1): 273-281. DOI: 10.4314/ijbcs.v15i1.24.

Fukangren Biopharm-Sci R. 2013.Dextrodoxylamine succinate. CN103467365A.

Jinyuan B, Zhichum S, Mei S. 2013. Preparation method of Doxylamine Succinate. CN103524403A

Kouamé TK, Siaka S, Kassi ABB, Soro Y. 2021. Détermination des teneurs en polyphénols totaux, flavonoïdes totaux et tanins de jeunes feuilles non encore ouvertes de Piliostigma thonningii (Caesalpiniaceae). International Journal of Biological and Chemical Sciences, 15(1): $\quad 97-105 . \quad$ DOI: 10.4314/ijbcs.v15i1.9.

Lee SY, Jung JW, Kim TH, Kim HD. 2015. Asymmetric synthesis of H1 receptor antagonist (R, R)-clemastine. Archives of Pharmacal Research, 38(12):2131-2136. DOI: 10.1007/s12272-015-0641-4.

McConathy J, Owens M. 2003. Stereochemis- 
try in Drug Action. Prim Care Companion J Clin Psychiatry, 5(2): 70-73. DOI: 10.4088/pcc.v05n0202.

Morrison J. 2012. Asymmetric Synthesis $\left(5^{\text {th }}\right.$ Edn). Academic Press: New York.

Nilesh S, Mahenda B, Nitin P. 2016. An efficient and safe process for synthesis of doxylamine succinate. World Journal of Pharmaceutical Sciences, 4(3): 478-481. http://www.wjpsonline.org/

Patti A. 2011. Green Approaches to Asymmetric Catalytic Synthesis. Springer Link (4):1-27.

Reshma J, Ragavi V, Nallamuthu A.2018. Role of Chirality in Drugs. Organic and Medicinal Chemistry, 5(3). DOI: 10.19080/OMCIJ.2018.05.555661

Samuel B, Adekunle YA. 2021. Isolation and structure elucidation of anti-malarial principles from Terminalia mantaly $\mathrm{H}$. Perrier stem bark. International Journal of Biological and Chemical Sciences, 15(1): 282-292. DOI: 10.4314/ijbcs.v15i1.25.

Tadiboyina S, Bannimath G, Bharathkumar I. 2015. Chiral separation of (d)- and (I) enantiomers of doxylamine succinate in rat plasma. Bulleting of Faculty of Pharmacy, Cairo University, 2015(53): 83-91.

DOI: http://dx.doi.org/10.1016/j.bfopcu.2015. 04.001 .

Wang X, Zak M, Maddess M, O'Shea P, Tillyer R, Grabowski E, Reider P. 2000. Highly asymmetric dihydroxylation of 1-aryl-1'pyridyl alkenes. Tetrahedron Letters, 25(41): 4865-48. DOI:10.1016/S00404039(00)00741-3 